\title{
PRAKTIK BAGI HASIL MUDHARABAH DALAM MENINGKATKAN JUMLAH NASABAH PADA PT. BPRS AMPEK ANGKEK CANDUNG SUMATERA BARAT
}

\author{
Lukman Hakim $^{1}$, Khodijah Ishak ${ }^{2}$, Adek Herlina ${ }^{3}$, Ratih Febriyani ${ }^{4}$, \& Dyanna Ernest ${ }^{5}$ \\ 1,2,3,4,\&5 Sekolah Tinggi Ilmu Ekonomi Syariah Bengkalis \\ Email:lukman_hakim94@ymail.com, khodijahishak2@gmail.com, stiesyariahbks@gmail.com
}

\begin{abstract}
ABSTRAK
Penelitian ini bertujuan untuk mengetahui hubungan antara bagi hasil dengan peningkatan jumlah nasabah PT. BPRS Ampek Angkek Candung Sumatera Barat pada tahun 2018 yang disebabkan karena adanya bencana alam yang terjadi di Sumatera Barat, hal ini mengakibatkan banyak nasabah yang menutup rekening dan menarik dananya untuk keperluan kesehatan dan pembayaran kerugian hasil bencana alam tersebut. Lima tahun belakangan PT. BPRS Ampek Angkek Candung mengalami krisi keuangan. Hal itu disebabkan oleh margin pembiayaan yang menurun dan juga tingkat kredit macet semakin tinggi, hal ini sangat mempengaruhi tingkat bagi hasil tabungan mudharabah. Dari hasil analisa dapat dilihat bahwa nasabah tidak melihat tingkat bagi hasil yang ditetapkan BPRS untuk tabungan mudharabah, nasabah lebih melihat kemudahan dan fasilitas yang diberikan oleh PT. BPRS Ampek Angkek Candung. Hal ini bisa dilihat dari hubungan terbalik antara tingkat bagi hasil mudharabah dengan jumlah nasabah yang menabung di PT. BPRS Ampek Angkek Candung.
\end{abstract}

Kata Kunci: Bagi Hasil, Mudharabah, Jumlah Nasabah, BPRS.

\section{ABSTRACT}

This study aims to determine the relationship between profit sharing and the increase in the number of customers of PT. BPRS Ampek Angkek Candung, West Sumatra. in 2018 due to a natural disaster that occurred in West Sumatra, this resulted in many customers closing their accounts and withdrawing their funds for health purposes and payment of losses resulting from the natural disaster. The last five years PT. BPRS Ampek Angkek Candung is experiencing a financial crisis. This was due to a declining financing margin and a higher level of bad loans, which greatly affected the rate of profit sharing for mudharabah savings. From the analysis results, it can be seen that customers do not see the level of profit sharing set by the BPRS for mudharabah savings, customers see the convenience and facilities provided by PT. BPRS Ampek Angkek Candung. This can be seen from the inverse relationship between the level of mudharabah profit sharing and the number of customers who save at PT. BPRS Ampek Angkek Candung.)

Keywords: Profit Sharing, Mudharabah, Number of Customers, BPRS. 


\section{PENDAHULUAN}

Bank Islam atau selanjutnya disebut dengan bank syari'ah adalah bank yang beroperasi dengan tidak mengandalkan pada bunga. Bank Islam adalah lembaga keuangan/perbankan yang operasional dan produknya dikembangkan berdasarkan landasan Al-Quran dan Hadits nabi Muhammad SAW atau dengan kata lain, bank Islam adalah lembaga keuangan yang usaha pokoknya memberikan pembiayaan dan jasa lainnya dalam lalu lintas pembayaran serta peredaran uang yang pengoperasianya disesuaikan degan prinsip syair'at Islam (Sumitro, 2015). Kehadiran Bank Syari'ah memberikan wajah baru dalam dunia perbankan, yang menunjukkan bahwa konsep Islam bukan hanya sekadar amalan ritual semata, namun jauh dari itu. Islam mempunyai konsep yang cukup luas serta ajarannya yang cukup komplit mencakup seluruh aspek muamalat (ekonomi) yang menjadi bagian terpenting dalam setiap gerakan kehidupan manusia (Anisah, 2016).

BPR Syariah merupakan salah satu lembaga keuangan yang perlu diperhatikan. Keberadaan BPR Syariah selalu di harapkan masyarakat kecil dan menengah. Karena BPR Syariah merupakan Lembaga Keuangan Syariah (LKS) yang terjun langsung dengan kehidupan masyarakat kecil yang sangat terbatas dengan ilmu pengetahuan dan juga materi, maka dari itu BPR Syariah mempunyai tugas, visi dan misi ke Islaman dalam aspek kehidupan masyarakat sebagai lembaga yang dapat di percaya (Diana, 2017).

Sistem bagi hasil merupakan sistem dimana dilakukannya perjanjian atau ikatan bersama didalam melakukan kegiatan usaha. Didalam usaha tersebut diperjanjikan adanya pembagian bagi hasil atas keuntungan yang akan didapat antara kedua belah pihak atau lebih. Bagi hasil dalam perbankan syariah merupakan ciri khusus yang ditawarkan kepada masyarakat dan didalam aturan syariah yang berkaitan dengan pembagian hasil usaha harus ditentukan terlebih dahulu pada awal akad. Besarnya penentuan porsi bagi hasil antara kedua belah pihak ditentukan sesuai kesepakatan besama dan harus terjadi dengan tanpa adanya unsur paksaan (Khasanah \& Gunawan, 2014).

$$
\text { Menurut Munthe }
$$

pengembangan bank berdasarkan prinsip bagi hasil adalah untuk mudharabah dan musyarakah memberikan pelayanan jasa kepada sebagian masyarakat Indonesia yang tidak dapat dilayani oleh perbankan yang sudah ada, karena bank-bank tersebut menggunakan sistem bunga. Dalam menjalani operasinya, bank syariah tidak mengenal peminjaman uang tetapi yang ada adalah kemitraan/kerjasama (mudharabah dan musyarakah) dengan prinsip bagi hasil, sementara peminjaman uang hanya dimungkinkan untuk tujuan sosial tanpa ada imbalan apapun. Sehingga dalam operasinya dikenal beberapa produk bank syariah antara lain produk dengan prinsip mudharabah dan musyarakah. Prinsip mudharabah dilakukan yang timbul menjadi resiko pemilik dana. Perinsip musyarakah adalah perjanjian antara pihak untuk menyertakan modal dalam suatu kegiatan ekonomi dengan pembagian keuntungan atau kerugian sesuai nisbah yang disepakati.

Ratusan tahun sudah ekonomi dunia didominasi oleh sistem bunga. Hampir semua perjanjian di bidang ekonomi dikaitkan dengan bunga, banyak Negara yang telah dapat mencapai kemakmurannya dengan sistem bunga ini di atas kemiskinan Negara lain sehingga terus-menerus terjadi kesenjangan. Pengalaman di bawah dominasi perekonomian dengan sistem bunga selama ratusan tahun membuktikan ketidak mampuannya kesenjangan ini. Di dunia, di antara Negara maju dan Negara berkembang kesenjangan itu semakin lebar, sedang didalam Negara berkembang kesenjangan itupun semakin dalam. Banyak fakta yang menggambarkan kesenjangan yang terjadi akibat diterapkannya sistem bunga, menjadikan kita lebih berfikir bahwa sistem bunga yang masih berlaku saat ini harus diganti dengan sistem lain yang dapat memberikan konstribusi yang lebih baik serta mempunyai konstribusi positif guna membangun perekonomian yang sejahtera. 
Salah satu sistem alternatif tersebut adalah sistem perbankan berdasarkan prinsip bagi hasil yang beroperasi beroperasi berdasarkan pada prinsip-prinsip Islam.

Pada dasarnya produk yang ditawarkan dalam perbankan syariah adalah produk penghimpunan dana (funding), produk penyaluran dana (financing), dan produk jasa (service) (Sari et al, 2017). Dasar pemikiran pengembangan bank berdasarkan prinsip bagi hasil adalah untuk mudharabah dan musyarakah memberikan pelayanan jasa kepada sebagian masyarakat Indonesia yang tidak dapat dilayani oleh perbankan yang sudah ada, karena bank-bank tersebut menggunakan sistem bunga. Dalam menjalani operasinya, bank syariah tidak mengenal peminjaman uang tetapi yang ada adalah kemitraan/kerjasama (mudharabah dan musyarakah) dengan prinsip bagi hasil, sementara peminjaman uang hanya dimungkinkan untuk tujuan sosial tanpa ada imbalan apapun. Sehingga dalam operasinya dikenal beberapa produk bank syariah antara lain produk dengan prinsip mudharabah dan musyarakah. Prinsip mudharabah dilakukan yang timbul menjadi resiko pemilik dana. Prinsip musyarakah adalah perjanjian antara pihak untuk menyertakan modal dalam suatu kegiatan ekonomi dengan pembagian keuntungan atau kerugian sesuai nisbah yang disepakati.

Sedangkan definisi mudharabah secara teknis adalah akad kerja sama usaha antara pemilik modal dan pengelola dana melakukan kegiatan usaha, laba dibagi atas dasar nisbah bagi hasil menurut kesepakatan kedua belah pihak, sedangkan bila terjadi kerugian akan ditanggung oleh si pemilik dana kecuali disebabkan oleh misconduct, negligence, atau violation oleh pengelola dana (Wahab, 2016).

Bagi hasil adalah salah satu kerja sama antara pemilik modal dan seseorang yang dilandasi oleh rasa tolong-menolong. Sistem bagi hasil merupakan sistem dimana dilakukannya perjanjian atau ikatan bersama didalam melakukan kegiatan usaha. Didalam usaha tersebut diperjanjikan adanya pembagian bagi hasil atas keuntungan yang akan didapat antara kedua belah pihak atau lebih. Bagi hasil dalam perbankan syariah merupakan ciri khusus yang ditawarkan kepada masyarakat dan didalam aturan syariah yang berkaitan dengan pembagian hasil usaha harus ditentukan terlebih dahulu pada awal akad. Besarnya penentuan porsi bagi hasil antara kedua belah pihak ditentukan sesuai kesepakatan bersama dan harus terjadi dengan tanpa adanya unsur paksaan.

Dalam prakteknya menurut Rakhmah dan Wahyuni (2016) mekanisme perhitungan bagi hasil dapat didasarkan pada dua cara yaitu profit sharing dan revenue sharing.

1) Profit sharing, perhitungan bagi hasil yang berdasarkan laba dari pendapatan dana, yaitu pendapatan usaha sebelum dikurangi dengan beban usaha untuk mendapatkan usaha tersebut.

2) Revenuene sharing, perhitungan bagi hasil yang berdasarkan pada pendapatan dari pengelola dana, yaitu pendapatan usaha sebelum dikurangi dengan beban usaha untuk mendapatkan pendapatan usaha tersebut.

\section{TINJAUAN PUSTAKA}

\section{Konsep Bagi Hasil Perbankan Syariah}

Sistem bagi hasil merupakan sistem di mana dilakukannya perjanjian atau ikatan bersama di dalam melakukan kegiatan usaha.

1. Profit sharing adalah perhitungan bagi hasil didasarkan kepada hasil bersih dari total pendapatan setelah dikurangi dengan biaya-biaya yang dikeluarkan untuk memperoleh pendapatan tersebut. Pada perbankan syariah istilah yang sering dipakai adalah profit and loss sharing, di mana hal ini dapat diartikan sebagai pembagian antara untung dan rugi dari pendapatan yang diterima atas hasil usaha yang telah dilakukan.

2. Revenue sharing dalam arti perbankan adalah perhitungan bagi hasil didasarkan kepada total seluruh pendapatan yang diterima sebelum dikurangi dengan biaya-biaya yang 
telah dikeluarkan untuk memperoleh pendapatan tersebut.

Menurut (Amri, 2012) bentuk-bentuk kontrak kerjasama bagi hasil dalam perbankan syariah secaara umum dapat dilakukan dalam empat akad, yaitu musyarakah, mudharabah, muzara'ah dan musaqoh. Namun, pada umumnya bank syariah menggunakan kontrak kerjasama pada akad musyarakah dan mudharabah. Jenis-jenis akad bagi hasil dalam perbankan syariah yaitu :

1) Musyarakah adalah akad kerjasama antara dua pihak atau lebih untuk suatu usaha tertentu dimana masing-masing pihak memberikan kontribusi dana /amal (expertise) dengan kesepakatan bahwa keuntungan dan resiko akan ditanggung bersama sesuai dengan kesepakatan.

2) Mudharabah adalah akad kerjasama antara shahibul mal dan pemberi modal $100 \%$ dengan mudharib yang memiliki keahlian.

Prinsip dasar konsep bagi hasil yang dikemukakan oleh (Muhammad, 2016) adalah sebagai berikut :

1) Bagi hasil tidak berarti meminjam uang, tetapi merupakan partisipasi dalam usaha.

2) Investor atau pemilik dana harus ikut menanggung resiko kerugian usaha sebatas proporsi pembiayaannya.

3) Para mitra usaha bebas menentukan, dengan persetujuan bersama, rasio keuntungan untuk masing-masing pihak, yang dapat berbeda dari rasio pembiayaan yang disertakan.

4) Kerugian yang ditanggung oleh masing-masing pihak harus sama dengan proporsi investasi mereka.

\section{Tabungan Mudharabah}

Tabungan mudharabah adalah tabungan yang dijalankan berdasarkan akad mudharabah. Mudharabah mempunyai dua bentuk, yakni mudharabah mutlaqah dan mudharabah muqayadah, yang perbedaan diantara keduanya terletak pada ada atau tidaknya persyaratan yang diberikan pemilik dana kepada bank dalam mengelola hartanya. Dalam hal ini, bank syariah bertindak sebagai mudharib (pengelola dana), sedangakan nasabah bertindak sebagai shahibul mal (pemilik dana). Bank syariah pada kapasitasnya sebagai mudharib, mempunyai kuasa untuk melakukan berbagai macam usaha yang tidak bertentangan dengan prinsip syariah serta mengembangkannya termasuk melakukan akad mudharabah dengan pihak lain. Namun, disisi lain bank syariah juga memiliki sifat sebagai seorang wali amanah (trustee), yang berarti bank harus berhati-hati dan bijaksana serta beritikad baik dan bertanggung jawab atas segala sesuatu yang timbul akibat kesalahan dan kelalaiannya. (Amri, 2012)

Dari hasil pengelolaan dana mudharabah, bank syariah akan membagihasilkan kepada pemilik dana sesuai dengan nisbah yang telah disepakati dan dituangkan dalam akad pembukaan rekening. Dalam mengelola dana tersebut bank tidak bertanggungjawab terhadap kerugian yang bukan disebabkan oleh kelalaiannya. Namun, apabila yang terjadi adalah mismanagement (salah urus), bank bertanggung jawab penuh terhadap kerugian tersebut.

Dalam mengelola harta mudharabah bank menutup biaya operasional tabungan dengan mengunakan nisbah keuntungan yang menjadi haknya. Disamping itu, bank tidak diperkenankan mengurangi nisbah keuntungan nasabah penabung tanpa persetujuan yang bersangkutan. Sesuai dengan ketentuan yang berlaku, PPH bagi hasil tabungan mudharabah dibebankan langsung kerekening tabungan mudharabah pada saat perhitungan bagi hasil.

Menurut Sari et al, (2017) perhitungan bagi hasil tabungan mudharabah dilakukan berdasarkan saldo rata-rata harian yang dihitung ditiap akhir bulan dan dibuku awal berikutnya. Rumusan perhitungan bagi hasil 
tabungan mudharabah adalah sebagai berikut :

\section{$\underline{\mathrm{HBH} \times \text { saldo } \mathrm{T} \mathrm{TBH}}$}

HK

HBH : Hari Bagi Hasil

Saldo : Jumlah Rata-rata Harian

TBH : Tingkat Bagi Hasil (Nisbah)

HK : Hari Kelender Nasabah

Dalam perhitungan bagi hasil tabungan mudharabah tersebut, hal- hal yang perlu diperhatikan adalah sebagai berikut :

1. Hasil perhitungan bagi hasil dalam angka satuan bulat tanpa mengurangi hak nasabah.

a) Pembulatan ke atas untuk nasabah.

b) Pembulatan ke bawah untuk nasabah.

2. Hasil perhitungan pajak dibulatkan keatas sampai puluhan terdekat. Dalam hal pembayaran bagi hasil, bank syariah menggunakan metode end the month, yaitu :

1) Pembayaran bagi hasil tabungan mudharabah dilakukan secara bulanan, yaitu pada tanggal tutup buku setiap bulan.

2) Bagi hasil bulan pertama dihitung secara proporsional hari efektif termasuk tanggal tutup buku, tapi tidak termasuk tanggal pembukaan tabungan.

3) Bagi hasil bulan terakhir dihitung secara proporsional hari efektif. Tingkat bagi hasil yang dibayarkan adalah tingkat bagi hasil tutup buku bulan terakhir.

4) Jumlah hari terakhir sebulan adalah jumlah hari kalender bulan yang bersangkutan (28 hari, 29 hari, 30 hari, 31 hari).

5) Bagi hasil bulanan yang diterima nasabah dapat diklasifikasi ke rekening lainnya sesuai permintaan nasabah.

\section{Rukun Mudharabah}

Faktor-faktor yang harus ada (rukun) dalam akad mudharabah adalah :

1) Pelaku, terdiri atas: Pemilik dana dan pengelola dana.

2) Objek mudharabah, berupa modal dan kerja.

3) Persetujuan kedua belah pihak (IjabQabul).

4) Nisbah keuntungan.

Sumber-Sumber Hukum Mudharabah :

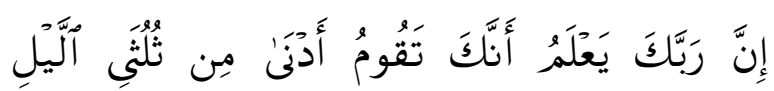

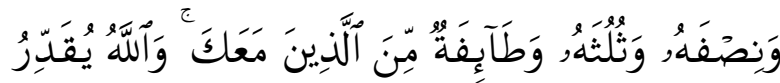

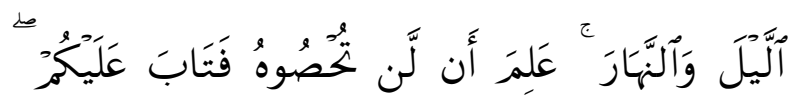

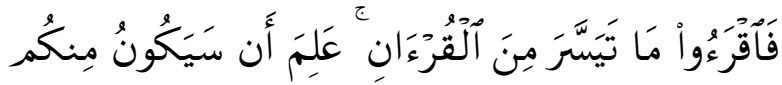

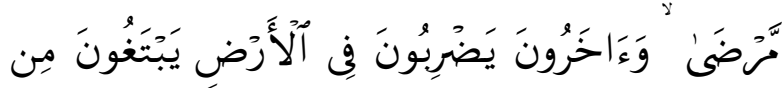

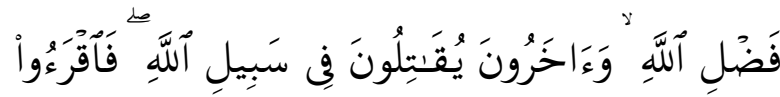

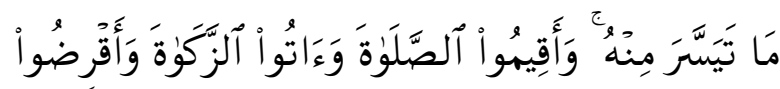

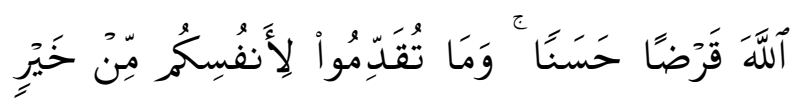

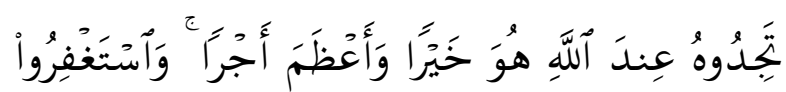

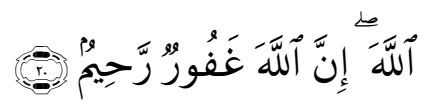

Artinya : Sesungguhnya Tuhanmu mengetahui bahwasanya kamu berdiri (sembahyang) kurang dari dua pertiga malam, atau seperdua malam atau sepertiganya dan (demikian pula) segolongan dari orang-orang yang bersama kamu. dan Allah menetapkan ukuran malam dan siang. Allah mengetahui bahwa kamu sekali-kali tidak dapat menentukan batasbatas waktu-waktu itu, Maka Dia memberi keringanan kepadamu, karena itu bacalah apa yang mudah (bagimu) dari Al Quran. Dia mengetahui bahwa akan ada di antara kamu orang-orang yang sakit dan orangorang yang berjalan di muka bumi mencari 
sebagian karunia Allah; dan orang-orang yang lain lagi berperang di jalan Allah, Maka bacalah apa yang mudah (bagimu) dari Al Quran dan dirikanlah sembahyang, tunaikanlah zakat dan berikanlah pinjaman kepada Allah pinjaman yang baik. dan kebaikan apa saja yang kamu perbuat untuk dirimu niscaya kamu memperoleh (balasan)nya di sisi Allah sebagai Balasan yang paling baik dan yang paling besar pahalanya. dan mohonlah ampunan kepada Allah; Sesungguhnya Allah Maha Pengampun lagi Maha Penyayang. (Q.S. Al Muzammil ayat 20)

\section{METODE PENELITIAN}

Penelitian dilakukan di PT. BPRS Ampek Angkek Candung Sumatera Barat. Data yang digunakan adalah data Primer berupa hasil wawancara dan data sekunder berupa laporan keuangan PT. BPRS Ampek Angkek Candung Sumatera Barat. Metode penelitian yang digunakan adalah dengan menggunakan metode deskriptif, yaitu serangkaian informasi yang digali berdasarkan fakta-fakta verbal bertujuan untuk mengambarkan sifat sesuatu yang tengah berlangsung pada saat riset dilakukan dan memeriksa sebab-sebab dari suatu gejala tertentu. Selanjutnya melakukan analisis terhadap perkembangan kuantitas Nasabah berdasarkan Laporan per Triwulan yang telah melewati proses Audit Internal sehingga peneliti dapat menarik beberapa kesimpulan.

\section{HASIL PENELITIAN PEMBAHASAN}

DAN

Menurut Sumitro (2015) bahwa menggunakan akad mudharabah mutlaqah, dalam hal ini bank syariah mengelola dana yang diinvestasikan oleh penabung sepenuhnya tanpa adanya intervensi dari pihak ketiga untuk proyek yang bersifat produktif, menguntungkan, halal dan memenuhi prinsip-prinsip syariah serta tidak dibatasi oleh spesifikasi jenis usaha, waktu dan daerah bisnis. Hasil keuntungannya akan dibagikan kepada pemilik dana (shohibul maal) sesuai akad nisbah bagi hasil yang telah disepakati. Fatwa Dewan Syari'ah Nasional Nomor : 02/DSNMUI/ IV/2000
Tentang Tabungan Ketentuan Umum Tabungan berdasarkan Mudharabah :

1. Dalam transaksi ini nasabah bertindak sebagai shahibul mal atau pemilik dana, dan bank bertindak sebagai mudharib atau pengelola dana. Dalam kapasitasnya sebagai mudharib, bank dapat melakukan berbagai macam usaha yang tidak bertentangan dengan prinsip syari'ah dan mengembangkannya, termasuk di dalamnya mudharabah dengan pihak lain. Modal harus dinyatakan dengan jumlahnya, dalam bentuk tunai dan bukan piutang. Pembagian keuntungan harus dinyatakan dalam bentuk nisbah dan dituangkan dalam akad pembukaan rekening. Bank sebagai mudharib menutup biaya operasional tabungan dengan menggunakan nisbah keuntungan yang menjadi haknya.

2. Bank tidak diperkenankan mengurangi nisbah keuntungan nasabah tanpa persetujuan yang bersangkutan. Teori serta fatwa dewan syariah nasional tersebut sesuai dengan yang terjadi dilapangan atau akad transaksi Tabungan Mudharabah yang digunakan oleh PT. BPRS Ampek Angkek Candung.

Berdasarkan hasil wawancara dan pengamatan, sistem bagi hasil tabungan mudharabah yang diterapkan oleh PT. BPRS Ampek Angkek Candung adalah sistem revenue sharing. Sistem ini mempunyai pengertian bahwa adanya pembagian hasil, penghasilan atau pendapatan antara shahibul maal (nasabah) dengan Mudharib (PT. BPRS). Jika pihak bank mengalami kerugian maka kerugian tersebut di tanggung oleh kedua belah pihak yaitu nasabah dan PT. BPRS Ampek Angkek Candung. Dengan asumsi bahwa kerugian tersebut disebabkan oleh bank sebagai mudharib dalam mengelola tabungan akan tetapi semua ada kesepakatan antara shahibul maal (nasabah) dengan mudharib (PT. BPRS) pada waktu melakukan akad.

Menurut (Mubarok, 2013) ada dua metode perhitungan bagi hasil yaitu Profit \& 
Loss Sharing dan Revenue Sharing. Namun pada PT. BPRS Ampek Angkek Candung metode perhitungan yang sering digunakan dalam perhitungan bagi hasil simpanan nasabah adalah metode Revenue Sharing. Dalam perhitungan bagi hasil, BPRS menggunakan konsep HI-1000 yang merupakan perhitungan hasil investasi atas setiap Rp. 1000 dana nasabah (DPK) yang dikelola oleh bank syariah. Hal ini digunakan untuk memudahkan nasabah dalam memahami cara perhitungan bagi simpanannya. Selain itu, penggunaan konsep HI 1000 dimaksudkan untuk menghindari penggunaan $\%$ yang sering dikonotasikan dengan bunga.

Penggunaan HI-1000 ini bermakna nasabah akan mendapatkan bagi hasil berapa rupiah setiap investasi Rp. 1000 yang di tabung di BPRS. Ada beberapa tahapan dalam menentukan Hi-1000 di BPRS, karena setiap bulan H-1000 selalu berubah-rubah nilainya, dikarenakan faktor pembiyaan dan keuntungan serta DPK yang diperoleh oleh BPRS.

Untuk mempermudah penulis menjelaskan maka penulis mengambil salah satu contoh data pada tahun 2018 :
Pembiyaan : Rp. 71.119.215.000

- Pemb. Murabahah : Rp. 71.062.215.000

- Pembiayaan Ijarah : Rp. $\quad 57.000 .000$

- Pembiayaan Mudharabah : -

- Pembiayaan Musyarakah : -

Pendapatan /bulan : Rp. 654.991.667

Dana Pihak Ketiga : Rp. 26.280.745.000

Bagi Hasil DPK

$\frac{\text { Dana Pihak Ketiga }}{\text { Pembiayaan }} x$ Pendapatan Pembiayaan

$: \frac{26.280 .745 .000}{71.119 .219 .000} \times 654.991 .667$

:Rp. 254.723 .545

Hi-1000: $\frac{\text { Bagi Hasil DPK }}{D P K} \times 1000$

$: \frac{254.723 .545}{26.280 .745 .000} \times 1000$

$: 9,21$

Jadi dari perhitungan di atas dapat dilihat bahwa Hi-1000 desember 2018 Rp. 9,21 . Ini bermakna bahwa pada hari bulan desember 2019 setiap investasi Rp.1000 di PT. BPRS Ampek Angkek Candung mendapatkan bagi hasil Rp. 9,21. Itu merupakan bagi hasil yang belum di bagikan sesuai porsi nisbah yang sudah di sepakati ketika awal akad. Penetapan nisbah bagi hasil untuk tabungan mudharabah sebesar 40\%:60\%, jadi 40\% untuk shahibul maal (nasabah) dan 60\% untuk mudharib (BPRS). Sedangkan rumus untuk menghitung bagi hasil nasabah sebagai berikut :

Bagi Hasil Nasabah $=\frac{\text { Rata-Rata Dana Nasabah }}{1000}$ X HI-1000 X $\frac{\text { Nisbah Nasabah }}{100}$

Penetapan bagi hasil di BPRS Ampek Angkek Candung dilakukan dengan terlebih dahulu menghitung HI-1000, yakni angka yang menunjukkan hasil investasi yang diperoleh dari penyaluran setiap Rp. 1.000 dana nasabah. Sebagai contoh HI-1000 bulan Desember 2018 adalah 9,21. Hal tersebut berarti bahwa dari setiap Rp. 1.000,- dana nasabah yang dikelola BPRS Ampek Angkek Candung akan menghasilkan Rp. 9,21 (HI-1000 sebelum bagi hasil). Apabila nisbah bagi hasil antara nasabah dan bank untuk tabungan 1 bulan adalah 40:60, maka dari Rp. 9,21 tersebut, untuk porsi nasabah dikalikan dahulu dengan $40 \%$ sehingga untuk setiap Rp. 1.000,- dana yang dimiliki, nasabah akan memperoleh bagi hasil sebesar Rp. 3,684 (berarti HI-1000 nasabah $=3,684$ rupiah).

Sebagai contoh, seorang nasabah pak Joko menyimpan tabungan Mudharabah di BPRS Ampek Angkek Candung pada bulan Desember dengan saldo bank sebagai berikut 
2022, Jurnal Tabarru' : Islamic Banking and Finance 5 (1) : 40 - 52

Tabel 1. Contoh Saldo Buku Tabungan Mudharabah

\begin{tabular}{cccc}
\hline Tanggal & Debit & Kredit & Saldo \\
\hline $01 / 12 / 2018$ & - & Rp. 1.000 .000 & Rp. 1.000 .000 \\
$05 / 12 / 2018$ & - & Rp. 1.000 .000 & Rp. 2.000 .000 \\
$11 / 12 / 2018$ & - & Rp. 1.000 .000 & Rp. 3.000.000 \\
$21 / 12 / 2018$ & - & Rp. 1.000 .000 & Rp. 4.000.000 \\
\hline Dalam mencari & saldo & rata-rata & Jumlah saldo 31 hari $=90.000 .000$
\end{tabular}

tabungan harian adalah sebagai berikut:

$01 / 12 / 13-04 / 12 / 13=4$ hari $\times 1.000 .000=: 31$ hari $=2.903 .225,8$

4.000 .000

$05 / 12 / 13-10 / 12 / 13=6$ hari $\times 2.000 .000=$ 12.000 .000

$11 / 12 / 13-20 / 12 / 13=10$ hari $\times 3.000 .000=$ 30.000 .000

$21 / 12 / 13-31 / 12 / 13=11$ hari $\times 4.000 .000=$ 44.000 .000

$$
\text { Rp 2.903.225,8,- }
$$

40

Bagi Hasil Nasabah $=$

1000

Sehingga saldo rata-rata pak Joko sebesar Rp. 2.903.225,8,- dengan jangka waktu 1 bulan. Diketahui nisbah tabungan 1 bulan 40:60. HI-1000 untuk bulan Desember 9,21 Maka untuk mengetahui nilai bagi hasil yang akan didapatkan Pak Joko adalah :

$=\longrightarrow$

Bagi Hasil Nasabah = Rp. 10.695,48

Equivalen Rate = bagi hasil nasabah / saldo rata-rata $\mathrm{x} 12$

$=10,695,48 / 2.903 .225,8 \times 12$

$=4,42 \%$ pa. (setara $4,42 \%$ per tahun $)$

Tabel 2. Jumlah Nasabah dan Nominal Tabungan Mudharabah PT. BPRS Ampek

Angkek Tahun 2015 sampai dengan 2019

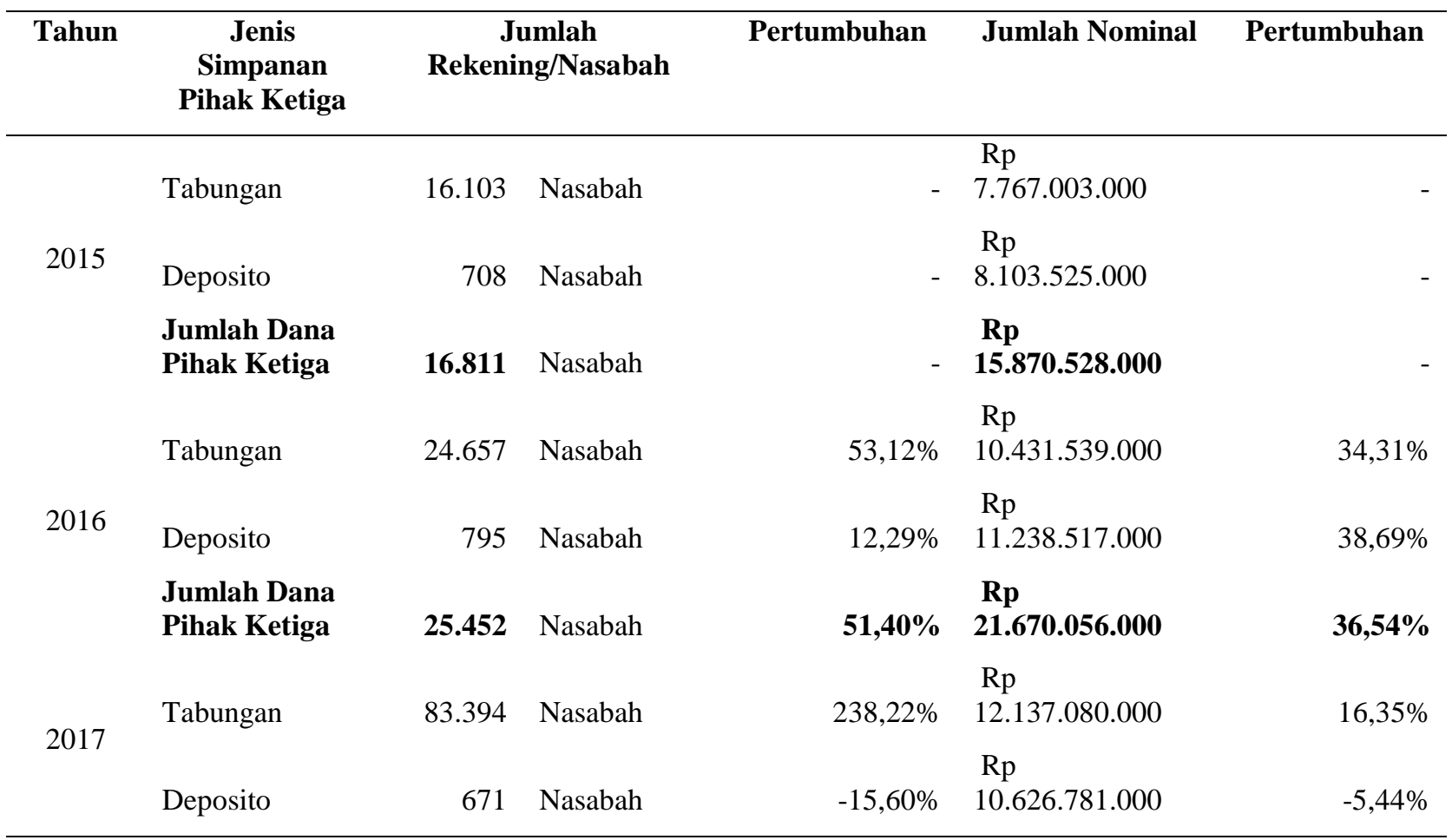


2022, Jurnal Tabarru' : Islamic Banking and Finance 5 (1) : 40 - 52

\begin{tabular}{|c|c|c|c|c|c|c|}
\hline & $\begin{array}{l}\text { Jumlah Dana } \\
\text { Pihak Ketiga }\end{array}$ & 84.065 & Nasabah & $230,29 \%$ & $\begin{array}{l}\mathrm{Rp} \\
22.763 .861 .000\end{array}$ & $5,05 \%$ \\
\hline \multirow{3}{*}{2018} & Tabungan & 1.727 & Nasabah & $-97,93 \%$ & $\begin{array}{l}\mathrm{Rp} \\
14.292 .042 .000\end{array}$ & $17,76 \%$ \\
\hline & Deposito & 637 & Nasabah & $-5,07 \%$ & $\begin{array}{l}\mathrm{Rp} \\
11.432 .180 .000\end{array}$ & $7,58 \%$ \\
\hline & $\begin{array}{l}\text { Jumlah Dana } \\
\text { Pihak Ketiga }\end{array}$ & 2.364 & Nasabah & $-97,19 \%$ & $\underset{25.724 .222 .000}{\operatorname{Rp}}$ & $13,00 \%$ \\
\hline \multirow{3}{*}{2019} & Tabungan & 32.113 & Nasabah & $1759,47 \%$ & $\begin{array}{l}\mathrm{Rp} \\
14.722 .539 .000\end{array}$ & $3,01 \%$ \\
\hline & Deposito & 702 & Nasabah & $10,20 \%$ & $\begin{array}{l}\mathrm{Rp} \\
11.958 .209 .000\end{array}$ & $4,60 \%$ \\
\hline & $\begin{array}{l}\text { Jumlah Dana } \\
\text { Pihak Ketiga }\end{array}$ & 32.815 & Nasabah & $1288,11 \%$ & $\begin{array}{l}\operatorname{Rp}_{26.680 .748 .000}\end{array}$ & $3,72 \%$ \\
\hline
\end{tabular}

Sumber : Data Olahan (2020)

Pada tahun 2016 jumlah nasabah tabungan sebanyak 83.394 nasabah, dengan tingkat pertumbuhan sebesar $53,12 \%$ dari tahun 2017 nominal tabungan keseluruhan Rp. 12.137.080.000 dengan tingkat pertumbuhan $16,35 \%$, jumlah nasabah deposito 671 nasabah dengan tingkat penurunan dari tahun $2017 \quad 15,60 \%$ dan nominal deposito Rp. 10.626 .781 .000 dengan tingkat penurunan sebesar $-5,44 \%$, dan jumlah keseluruhan nasabah (Tabungan dan deposito) sebanyak 84.065 nasabah dengan tingkat pertumbuhan 230,29\% dengan jumlah keseluruhan Rp. 22.763.861.000 dengan tingkat pertumbuhan sebesar 5,05\% dari tahun 2017. Secara keseluruhan terjadi peningkatan dari tahun
2015 hanya pada jumlah deposito dan nasabah deposito, karena pada tahun ini BPRS fokus kepada tabungan.

Dalam penelitian ini penulis ingin melihat seberapa jauh hubungan antara tingkat bagi hasil (Hi-1000) terhadap jumlah nasabah yang menabung pada PT. BPRS Ampek Angkek Candung Bukit Tinggi. Dalam penelitian ini penulis menguraikan bagi hasil (Hi-1000) selama 5 tahun terakhir yaitu pada tahun 2015 sampai dengan 2019. Sebelumnya sudah di bahan pada BAB IV poin B tentang perhitungan HI-1000 yang ditetapkan BPRS Ampek Angkek Candung. Disini penulis merangkum dalam satu tabel sebagai berikut :

Tabel 3. Perhitungan Bagi Hasil (HI-1000) PT. BPRS Ampek Angkek Candung Tahun 2005 sampai dengan 2019

\begin{tabular}{|c|c|c|c|c|c|c|c|}
\hline Jenis Akun & No & Rumus & 2015 & 2016 & 2017 & 2018 & 2019 \\
\hline Pembiayaan & I & & 29.911 .429 .000 & 38.191 .659 .000 & 49.615 .082 .000 & 65.586 .202 .000 & 71.119 .215 .000 \\
\hline Pendapatan Pembiayaan & II & & 314.127 .917 & 391.783 .167 & 471.929 .167 & 608.383 .667 & 654.991 .667 \\
\hline DPK & III & & 15.870 .188 .000 & 21.670 .056 .000 & 22.763 .861 .000 & 25.724.222.000 & 26.680 .745 .000 \\
\hline Bagi Hasil DPK & IV & $*(\mathrm{III} / \mathrm{I}) \mathrm{xII}$ & 166.667 .701 & 222.298 .884 & 216.525 .490 & 238.620 .259 & 245.723 .545 \\
\hline HI /1000 & $\mathrm{V}$ & $* *(\mathrm{IV} / \mathrm{III}) \times 1000$ & 10,502 & 10,258 & 9,512 & 9,276 & 9,210 \\
\hline $\begin{array}{l}\text { Bagi Hasil Nasabah } \\
\text { (Asumsi jika saldo rata- } \\
\text { rata nasabah } 10 \text { juta) }\end{array}$ & VI & $* * *$ & 42.008 & 41.033 & 38.047 & 37.104 & 36.839 \\
\hline Equivalen Rate & VII & **** & $5,04 \%$ & $4,92 \%$ & $4,57 \%$ & $4,45 \%$ & $4,42 \%$ \\
\hline
\end{tabular}

Sumber : Data Olahan (2020) 
Keterangan

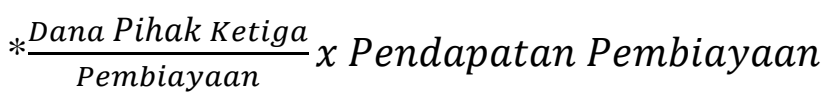

** $\frac{\text { Bagi Hasil DPK }}{D P K} \times 1000$

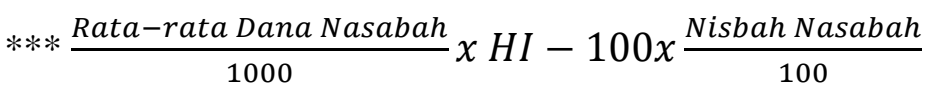

$* * * * \frac{\text { Bagi Hasil Nasabah }}{\text { Saldo Rata-rata }} \times 12$

Dari data diatas dapat dilihat bahwa setiap tahun HI-1000 mengalami penurunan, hal ini disebabkan peningkatan jumlah pembiayaan yang disalurkan meningkat tidak diikuti dengan peningkatan laba bagi hasil dan margin murabahah, karena semakin tinggi laba yang diperoleh BPRS maka semakin tinggi juga bagi hasil yang didapatkan oleh nasabah, hal ini dikarenakan banyaknya pembiayaan yang belum tertagih

Tabel 4. Hubungan antara Jumlah Nasabah dengan Bagi Hasil pada PT. BPRS Ampek Angkek Candung Tahun 2015 sampai dengan 2019

\begin{tabular}{crrrr}
\hline Tahun & HI-1000 & Pertumbuhan & Jumlah Nasabah & \multicolumn{1}{c}{ Pertumbuhan } \\
\hline 2015 & 10,502 & & 16.811 & \\
\hline 2016 & 10,258 & $-2,32 \%$ & 25.452 & $230,29 \%$ \\
\hline 2017 & 9,512 & $-7,28 \%$ & 84.065 & $-97,19 \%$ \\
\hline 2018 & 9,276 & $-2,48 \%$ & 2.364 & $1288,11 \%$ \\
\hline 2019 & 9,210 & $-0,71 \%$ & 32.815 & \\
\hline
\end{tabular}

Sumber : Data Olahan (2020)

Dari tabel di atas dapat dilihat bahwa pada tahun 2015 HI-1000 sebesar 10,502 sedangkan jumlah nasabah sebanyak 16.811 nasabah, sedangkan pada tahun 2016 HI1000 sebesar 10,258 sedangkan jumlah nasabah 25.452 nasabah, hal ini berbanding terbalik, HI-1000 2016 mengalami penurunan sebesar 2,32\% sedangkan jumlah nasabah mengalami peningkatan sebesar $51,40 \%$, pada tahun 2016 ini membuktikan bahwa HI-1000 atau tingkat bagi hasil tidak mempengaruhi jumlah nasabah yang ingin menabung pada PT BPRS Ampek Angkek Candung. Hal ini sejalan dengan penelitian yang dilakukan oleh (Amri, 2012) dan (Munthe, 2014).

Pada tahun 2017 tingkat bagi hasil HI-1000 sebesar 9,512 sedangkan jumlah nasabahnya sebanyak 84,065 nasabah/rekening. Kembali lagi pada tahun atau kredit macet yang terjadi di BPRS sehingga keuntungan yang di dapatkan BPRS tidak maksimal, tidak hanya itu margin yang ditetapkan BPRS untuk pembiayaan semakin kecil, hal ini memicu pertumbuhan pendapatan laba bagi hasil tidak sesignifikan pertumbuhan pembiayaan yang diberikan kepada nasabah. Sehingga mengakibatkan HI-1000 juga semakin menurun. Hal ini sejalan dengan penelitian yang dilakukan oleh (Mursalina, 2017) dan (Lindiawatie dan Shahreza, 2018).

Untuk melihat lebih jelas maka penulis menggunakan tabel berikut untuk memperjelas seberapa besar hubungan antara tingkat bagi hasil (HI-1000) terhadap peningkatan jumlah nasabah pada PT. BPRS Ampek Angkek Candung Tahun 2015 sampai dengan 2019. 
menurunnya jumlah nasabah ini bukan karena menurunnya tingkat bagi hasil, namun dikarenakan bencana alam sehingga nasabah banyak yang menarik seluruh dana bahkan menutup rekening dengan tujuan agar bisa menarik seluruh dana yang tersimpan didalam rekening.

Pada tahun 2018 tingkat bagi hasil HI-1000 sebesar 9,210 sedangkan jumlah nasabahnya sebanyak 32.815 nasabah/rekening. Kembali lagi pada tahun 2019 berbanding terbalik antara tingkat bagi hasil dengan jumlah nasabah/rekening. Tingkat bagi hasi mengalami penurunan sebesar $0,71 \%$ sedangkan jumlah nasabah meningkat sebesar $1.288,11 \%$. Kita juga bisa melihat bahwa pada tahun ini pengaruh berbanding terbalik, hal ini juga membuktikan bahwa tingkat bagi hasil tidak mempengaruhi jumlah nasabah yang menabung, hal ini bisa dilihat pada tahun 2019 HI-1000 cenderung menurun namun jumlah nasabah yang menabung cenderung meningkat sebesar $1.288 \%$.

\section{Gambar 1. Pertumbuhan Jumlah Nasabah DPK PT. BPRS Ampek Angkek Candung} Tahun 2015 sampai dengan 2019

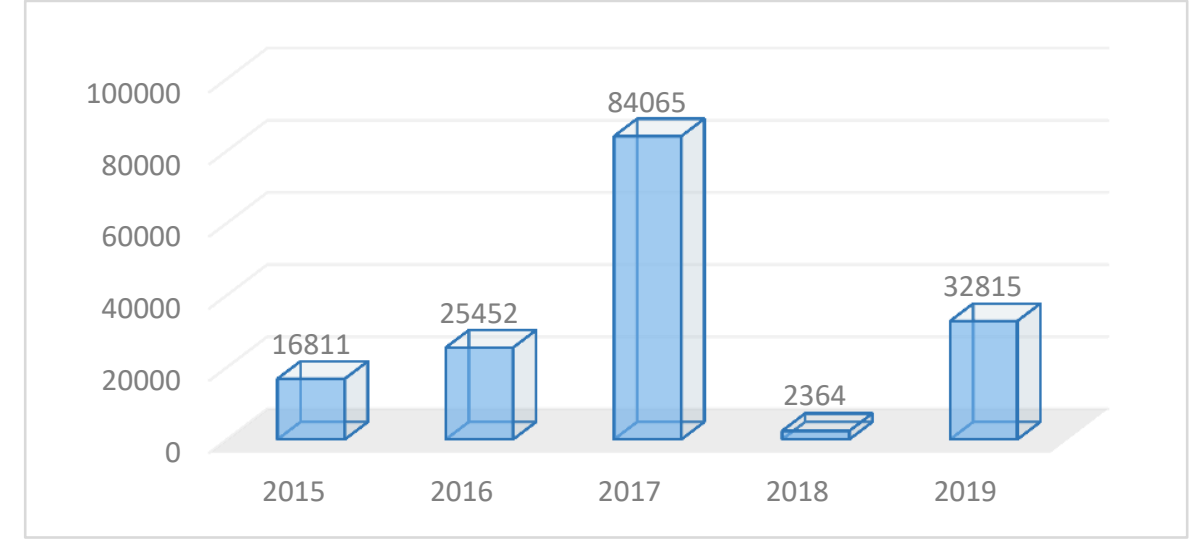

Sumber : Data Olahan (2020)

Perlu digaris bawahi adalah selama tahun 2015 sampai dengan 2019 nisbah bagi hasil PT. BPRS Ampek Angkek Candung adalah sebesar 40:60 tidak pernah berubah, dan dari hasil olahan data diatas bahwa selama 5 tahun terakhir jumlah nasabah selalu meningkat kecuali pada tahun 2018 yang disebabkan karena adanya bencana alam yang terjadi di Sumatera Barat, hal ini mengakibatkan banyak nasabah yang menutup rekening dan menarik dananya untuk keperluan kesehatan dan pembayaran kerugian hasil bencana alam tersebut. Sedangkan nominal tabungan mudharabah dari tahun 2015 sampai dengan tahun 2019 tidak pernah mengalami penurunan walaupun tahun 2018 terjadi bencana alam yang banyak merugikan warga yang juga sekaligus nasabah PT. BPRS Ampek Angkek Candung. Dan tingkat bagi hasil atau HI1000 dari tahun 2015 sampai dengan tahun 2019 mengalami penurunan setiap tahunnya yang disebabkan oleh margin pembiyaan yang menurun dan juga tingkat kredit macet semakin tinggi, hal ini sangat mempengaruhi tingkat bagi hasil tabungan mudharabah.

Dari hasil analisa dapat dilihat bahwa nasabah tidak melihat tingkat bagi hasil yang ditetapkan BPRS untuk tabungan mudharabah, nasabah lebih melihat kemudahan dan fasilitas yang diberikan oleh PT. BPRS Ampek Angkek Candung. Hal ini bisa dilihat dari hubungan terbalik antara tingkat bagi hasil mudharabah dengan jumlah nasabah yang menabung di PT. BPRS Ampek Angkek Candung. Hal yang sama juga terjadi pada penelitian yang dialkukan oleh (Saputri, 2017) dan (Samsudin, 2012).

\section{KESIMPULAN}

Tingkat bagi hasil atau HI-1000 dari tahun 2015 sampai dengan tahun 2019 mengalami penurunan setiap tahunnya yang disebabkan oleh margin pembiyaan yang menurun dan juga tingkat kredit macet semakin tinggi, hal ini sangat mempengaruhi tingkat bagi hasil tabungan mudharabah. 
Kondisi tersebut diperparah oleh bencana alam yang terjadi sehingga mempengaruhi nasabah. Dari hasil analisa dapat dilihat bahwa nasabah tidak melihat tingkat bagi hasil yang ditetapkan BPRS untuk tabungan mudharabah, nasabah lebih melihat kemudahan dan fasilitas yang diberikan oleh PT. BPRS Ampek Angkek Candung. Hal ini bisa dilihat dari hubungan terbalik antara tingkat bagi hasil mudharabah dengan jumlah nasabah yang menabung di PT. BPRS Ampek Angkek Candung.

\section{DAFTAR PUSTAKA}

Amri, Kholifatul. 2012. Pelaksanaan Nisbah Bagi Hasil Revenue Sharing Akad Mudharabah Di Bank Pembiayaan Rakyat Syariah Muamalat Harkat Bengkulu. Skripsi Sarjana, Program Studi Ekonomi Islam. IAIN Bengkulu.

Anisah, Yuli Mizan. 2012. Pengaruh Sistem Profit Sharing Terhadap Keinginan Nasabah Untuk Berinvestasi pada Baitul Maal Taamwil (BMT) di Kota Banda Aceh. Jurnal Ekonomi dan Bisnis, 12(1).

Diana, Susanti Mei. 2017. Pengaruh Pengetahuan, Lokasi, Kualitas Pelayanan, Dan Bagi Hasil Terhadap Keputusan Anggota Menabung Di BMT Bina Umat Sejahtera Kalijambe. Skripsi. Fakultas Ekonomi dan Bisnis Islam Institut Agama Islam Negeri Surakarta.

Khasanah, Yulika., \& Gunawan, Ari Indra. 2014. Pengaruh Sistem Bagi Hasil Terhadap Keputusan Menjadi Nasabah Bank Syariah di Kota Cirebon. Jurnal Educonomi Volume, 2(1), p. 37-46.

Lindiawatie., \& Shareza, Dhona. 2018. Peran Koperasi Syariah BMT Bumi Dalam
Meingkatkan Kualitas Usaha Mikro. Al-Urban : Jurnal Ekonomi Syariah Dan Filantropi Islam, 2(1), p. 1-12.

Mubarok, Jaih. 2013. Hukum Ekonomi Syariah : Akad Mudharabah. Fokusmedia. Bandung.

Muhammad. 2016. Sistem Bagi Hasil Dan Pricing Bank Syariah. UII Press. Yogyakarta.

Munthe, Safaruddin. 2014. Faktor-Faktor Yang Mempengaruhi Minat Nasabah Menabung Pada Tabungan Mudharabah di Bank Muamalat Cabang Balai Kota. Masters thesis, Pascasarjana UIN Sumatera Utara.

Mursalina, Desi. 2017. Pengaruh Pelayanan, Produk Tabungan Dan Bagi Hasil Terhadap Minat Nasabah Pada Produkpembiayaan Produktif Investasi IB Bank Sumsel Babel Syariah Kantor Cabang Palembang. Skripsi, UIN Raden Fatah Palembang.

Rakhmah, Silvia Miftakhur., \& Wahyuni, Sri. 2016. Pengaruh Persepsi Mahasiswa Tentang Bank Syariah Terhadap Minat Menabung di Perbankan Syariah. JURNAL PENDIDIKAN EKONOMI: Jurnal Ilmiah Ilmu Pendidikan, Ilmu Ekonomi dan Ilmu Sosial (JPE), 10(1).

Samsudin, Muhammad. 2012. Persepsi Nasabah Terhadap Sistem Bagi Hasil Di Lembaga Keuangan Mikro Syariah. Skripsi, IAIN Mataram.

Saputri, Riska. 2017. Pengaruh Bagi Hasil Tabungan Mudharabah Dan Deposito Mudharabah Terhadap Laba Bersih PT. Bank Syariah Mandiri, Tbk Periode 2009-2016. Skripsi, Fakultas 
Ekonomi dan Bisnis. Universitas Islam Negeri Raden Intan Lampung.

Sari, Novita Erliana., Amah, Nik., \& Wirawan, Yahya Reka. 2017. Penerapan Bagi Hasil dan Pengaruhnya Terhadap Keputusan Menabung Pada Nasabah Bank Muamalat Kantor Cabang Madiun. Promosi: Jurnal Pendidikan Ekonomi UM Metro, 5(2), p. 60-67.

Sumitro, Warkum. 2015. Asas-asas Perbankan Islam Lembaga-lembaga Terkait di Indonesia. PT. Raja Grafindo Persada. Jakarta.

Wahab, Wirdayani. 2016. Pengaruh Tingkat Bagi hasil Terhadap Minat Menabung. JEBI (Jurnal Ekonomi dan Bisnis Islam), 1(2), p. 167-184. 